\title{
MODELING OF QUEUE LENGTH AT RAILWAY LEVEL CROSSING CLOSE TO A SIGNALIZED INTERSECTION (CASE STUDY: JAGIR WONOKROMO SURABAYA RAILWAY LEVEL CROSSING)
}

\author{
Nur Fajar Aprilia Sari ${ }^{*}$, Hera Widyastutia
}

\begin{abstract}
In Indonesia, there are still many level crossings, namely between railways and highways. This will cause congestion, in the form of queue length of vehicles that stop due to the gate closing at the railway level crossing. In addition, level railway crossing located near a signalized intersection can also affect the performance of signalized intersections. This is due to the queue length of vehicle that can interfere with intersection. Based on the problem, it is necessary to build two models. The first model is between the gate closing time at level crossing with the length and speed of the train using multiple regression method. The second model is between the gate closing time at level crossing and the queue length of vehicles using a simple regression method. The result of first model shows that the gate closing time at level crossing has a positive relationship with the length of train and a negative relationship with the speed of train. The relationship among these three variables is $y=-2.083 x_{1}+0.637 x_{2}$ $+249.930 . Y$ is described as the gate closing time at level crossing, while $x_{1}$ is the speed of train and $x_{2}$ is the length of train. While the result of second model regarding the relationship between the gate closing time at level crossing with the queue length of vehicles has a positive effect in each direction. The relationship between two variables is $y=1.2329 x+84.725$ for East Jagir Wonokromo Street from east to west direction and $y=0.5176 x+24.44$ for East Jagir Wonokromo Street from west to east direction. $Y$ is described as the gate closing time at level crossing and $x$ is described as the queue length of vehicles.
\end{abstract}

Keywords: Railway level crossing, signalized intersection, queue length, simple regression, multiple regression

\section{INTRODUCTION}

East Java is a very dense province with a population of $39,292,972$ inhabitants and the rate of population growth continues to increase by $0.64 \%$ annually [1]. One of the cities in East Java is Surabaya. The average population growth in Surabaya is $0.435 \%$ annually [2]. As along with the growth of motor vehicle volume in Surabaya continues to increase between 6-7\% annually [3]. With the increasing volume of vehicles causing congestion at several points in Surabaya. One of the congestion points in Surabaya is congestion caused by a level crossing located near the intersection of Jagir Wonokromo area. Under existing regulations, when a train passes through a level crossing there must be a closure of the crossing bar and there is a temporary halt of the flow of highway traffic resulting in an increase in the queue length at the intersection arm [4]. This is in accordance with Law No. 23 of 2007 Article 124 which implies "at the intersection of a level crossing between a railway and a highway, highway users are obliged to prioritize train travel", so that if the crossing of the two modes is still a level crossing, hence closure of the gate must be done at the crossing when the train passes at an intersection [5].

In addition, a railway level crossing located near a signalized intersection has a major effect on intersection, which disrupts traffic flow intervals and can lead to long congestion. This is because when a train passes, the waiting time of the vehicle becomes longer resulting in a spillage of traffic to an adjacent intersection and causing congestion [6]. One of the causes of congestion around a level crossing is the duration gate closing time before the train passes through the crossing and when the train passes through the crossing [7]. The gate closing time at level crossing had a significant effect on the queue length [8]. The duration when a train passes through its own level crossing is at least

${ }^{a}$ Civil Engineering Department, Institut Teknologi Sepuluh Nopember, ITS Campus, Sukolilo, Surabaya 60111, Indonesia. Corresponding author email address: hera.widyastuti@ce.its.ac.id
60 seconds, which is the distance between the gate closing time of a railway level crossing and the time the train crosses a level crossing, depending on the length of the train and other factors, one of which considers safety for road crossings [7].

From these problems, a model of the relationship between the gate closing time at level crossing with the length and the speed of the train. In addition, it is also necessary to create a model of the relationship between the gate closing time at level crossing with queue length of vehicles around the Jagir Wonokromo area of Surabaya. The signalized intersection located on Jagir Wonokromo Street in Surabaya needs to be reviewed because the distance between the railway crossing and the signalized intersection is only 25 meters. If the queue length of vehicles due to the gate closing at the railway level crossing on East Jagir Wonokromo Street, which leads to the level crossing (from west to east) exceeds this distance, it is possible to create traffic congestion at the signalized intersection. It is also one of the roads that connects to several activity centers in Surabaya, such as offices, malls, markets, and Wonokromo Railway Station.

\section{RESEARCH SIGNIFICANCE}

Level crossing between a railway and a highway should be made not same level crossing, unless it is temporary [5]. If there are still many level crossings will cause a large number of vehicles to stop during peak hours when there is a closure of the crossing bars due to passing trains that will cause congestion [7]. In addition, level crossing located near signalized intersection will cause problems. If the queue length of vehicles caused by the closure of level crossings exceeds the distance between level crossings and signalized intersection, it will cause the queue length of vehicles to the middle of the signalized intersection, causing traffic congestion. Therefore, in this study, a model of the duration gate closing time at level crossing with the speed and length of the train using multiple linear regressions is made, as well as the duration of the gate 
closing time at level crossing with the queue length of vehicles at each direction of the signalized intersection and the road with simple linear regression is modeled. This modeling is expected to contribute to traffic management at signalized intersection near railway level crossing to reduce the queue length of vehicles, considering the gate closing time at railway level crossing is affected by several factors.

\section{METHODOLOGY}

The research methodology in this paper consists of 5 stages. The first stage in this study is data collection. The primary data needed in this study are geometric data of signalized intersection and road, vehicle volume data, phase data on signalized intersection, cycle time data of signalized intersection, data about queue length in the field, data of the schedule of passing trains, data of the speed of passing trains, data of the length of train, and long data on the gate closing time of a level crossing cross. After obtaining primary data, then conducted traffic performance analysis, analysis of queue length determination, comparison analysis between two queue length results, and modeling.

\section{A. TRAFFIC PERFORMANCE}

The traffic performance reviewed is on each arm of Jagir Wonokromo Signalized Intersection and East Jagir Wonokromo Street (there is a level crossing). Figure 1 shows the location of this study. The signalized intersection performance was analyzed using the reference of Road Capacity Guidelines of Indonesia (PKJI) 2014 for Signalized Intersection Capacity, while the road performance was analyzed using the reference of Road Capacity Guidelines of Indonesia (PKJI) 2014 for Urban Road Capacity.

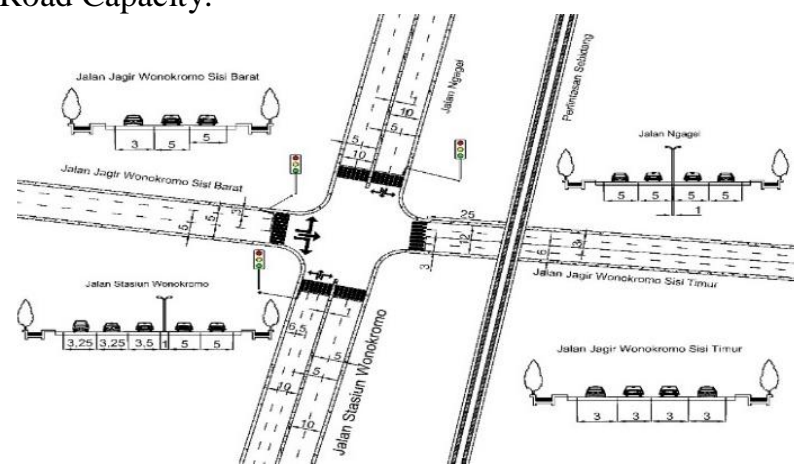

Figure 1 Object's Research Location

The capacity at the signalized intersection is obtained from the multiplication result between the saturated flow that has been adjusted to the geometric condition of the signalized intersection with the ratio of green time and cycle time in each phase [9]. While the capacity on the road is obtained from the multiplication of the basic capacity based on the type of road with adjustment factors according to the geometric conditions of the road [10].

The queue length at each signalized intersection is obtained from the summation of the average number of vehicle queues at the beginning of the green light signal and the number of stalled vehicles left over from the previous green phase [9].
The degree of saturation is obtained from the result of the ratio between the flow of traffic passing on each short circuit of the signalized intersection and the road for an hour with the capacity or ability of each short circuit and the road to accommodate the number of vehicles within an hour. The value of degree of saturation that is close to 0 indicates an unsaturated traffic flow, while a value of degree of saturated that is close to 1 indicates a saturated traffic flow.

\section{B. QUEUEING ANALYSIS}

To find out the delays that cause queue length of vehicles on East Jagir Wonokromo Street (there is a level crossing) due to the gate closing time at railway level crossing can be done by calculating the queue length using the queueing analysis method [11]. In addition, this queueing analysis method can also be used to determine the queue length of vehicles at each direction at signalized intersection when the red light is lit due to the gate closing of the railway level crossing [12]. Figure 2 shows the time relationship of traffic flow due to red lights and green light at signalized intersection with saturated condition [13]. In queueing analysis or derived formula of shocked wave, the queue length that occurs is affected by the duration gate closing time and release time only [14]. The following is the formula of the queueing analysis method:

$$
\begin{aligned}
T_{Q} & =\frac{\mu \cdot r}{\mu-r} \\
Q_{M} & =\frac{\lambda . r}{3600} \\
Q_{L} & =Q_{L} x \frac{20}{L_{M}}
\end{aligned}
$$

Information:

$\mathrm{T}_{\mathrm{Q}} \quad=$ Queue Duration Time (seconds)

$\lambda=$ Arrival Rate (light vehicle unit/hour)

$\mu \quad=$ Service Rate (light vehicle unit/hour)

$\mathrm{r} \quad=$ Effective Red Period (seconds)

$\mathrm{Q}_{\mathrm{M}} \quad=$ Maximum Queue Length (light vehicle unit)

$\mathrm{Q}_{\mathrm{L}} \quad=$ Vehicle Queue Length $(\mathrm{m})$

$\mathrm{L}_{\mathrm{M}} \quad=$ Width of Road Entrance (m)

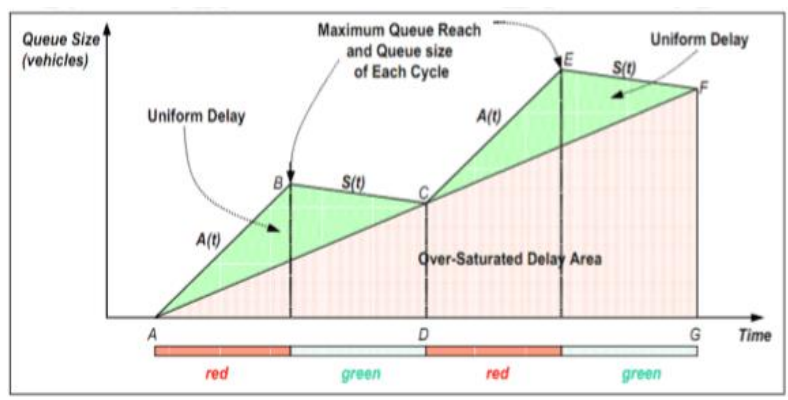

Figure 2 Time Relationship with Traffic Flow When There are Red and Green Lights in Oversaturated Intersection Conditions [13]

\section{REGRESSION}

The results of data analysis in the form of traffic characteristics are then processed to create two model. The first model is the relationship between the duration gate 
closing time at the level crossing with the length of train and the speed of the train using multiple regression methods with the SPSS as a support program. The second model is the relationship between the duration gate closing time at level crossing and the queue length of vehicles using a simple linear regression method with Microsoft Excel as a support program. Multiple linear regression analysis are used to obtain more than one free variable relationship, while simple linear regression analysis is used to obtain a single free variable relationship [15]. Linear regression form as follows:

$$
y=a+b x
$$

\section{ANALYSIS AND DISCUSSIONS}

\section{A. TRAFFIC ANALYSIS}

The vehicle volume data obtained through the survey was then converted into a light vehicle unit (LVU) multiplied by the equivalent of light vehicles in accordance with PKJI 2014, which for signalized intersection is based on the type of each direction of signalized intersection, while for road is based on the type of road and total traffic flow. Then obtained recapitulation of traffic flow peak hour condition at $08.45-09.45$ for each direction of signalized intersection and road. Once the peak hour traffic flow is obtained, then it can be done traffic performance analysis. For signalized intersection, it is necessary to calculate capacity (C), degree of saturation (DS) and queue length (QL). The results of the calculation of capacity (C), degree of saturation (DS), and queue length at each direction of Jagir Wonokromo Signalized Intersection can be seen in Table 1. As for East Jagir Wonokromo Street, traffic performance can be known by calculating capacity (C) and degree of saturation (DS). The results of the calculation of capacity (C) and degree of saturation (DS) on East Jagir Wonokromo Street can be seen in Table 2 .

Tabel 1 Capacity, Degree of Saturation, dan Queue Length of Jagir Wonokromo Signalized Intersection

\begin{tabular}{lccc}
\hline \multicolumn{1}{c}{ Each Direction } & $\begin{array}{c}\mathrm{C} \\
(\mathrm{lvu} / \mathrm{hr})\end{array}$ & DS & $\begin{array}{c}\text { Queue } \\
\text { Length }(\mathrm{m})\end{array}$ \\
\hline South Right & 379 & 0.777 & 100 \\
South & 1609 & 0.777 & 141 \\
West & 1428 & 0.777 & 89 \\
North & 2420 & 0.378 & 44 \\
\hline
\end{tabular}

Table 2 Capacity and Degree of Saturation of East Jagir Wonokromo Street

\begin{tabular}{cccc}
\hline Direction & $\begin{array}{c}\text { Flow } \\
(\mathrm{lvu} / \mathrm{hr})\end{array}$ & $\mathrm{C}(\mathrm{lvu} / \mathrm{hr})$ & $\mathrm{DS}$ \\
\hline West - East & 2281 & 2921 & 0.781 \\
East - West & 2883 & 2921 & 0.987 \\
\hline
\end{tabular}

\section{B. TRAFFIC ANALYSIS WHEN TRAIN PASSING THROUGH RAILWAY LEVEL CROSSING}

Traffic performance analysis when there is a train passing is the same as the traffic performance analysis when no trains are passing. Before conducting traffic performance analysis when there is a train passing, it is necessary to convert the volume of vehicles. This is because in traffic analysis using PKJI 2014 method, hourly traffic volume data is required, but in traffic analysis when the train passes through the crossing, vehicle volume data is obtained on one new cycle. The new cycle time for signalized intersection is the time of the signalized intersection cycle that occurs when the closing of a railway crossing due to a passing train in seconds, while for the road is the the duration gate closing time at level crossing in seconds. Examples of vehicle volume conversion on each direction of Jagir Wonokromo Signalized Intersection can be seen in Table 3 and on the East Jagir Wonokromo Street can be seen in Table 4.

Table 3 Vehicle Volume Conversion at Jagir Wonokromo Signalized Intersection

\begin{tabular}{ccccc}
\hline Time & $\begin{array}{c}\text { Cycle } \\
\text { Time } \\
\text { (seconds) }\end{array}$ & $\begin{array}{c}\text { Vehicle } \\
\text { per } \\
\text { cycle }\end{array}$ & $\begin{array}{c}\text { Conversion } \\
\text { times } \\
\text { factor }\end{array}$ & $\begin{array}{c}\text { Conversion } \\
\text { (vehicle/hr) }\end{array}$ \\
\hline 08.23 .09 & 160 & 102 & 23 & 2295 \\
08.43 .06 & 130 & 172 & 28 & 4763 \\
\hline
\end{tabular}

Table 4 Vehicle Volume Conversion on East Jagir Wonokromo Street

\begin{tabular}{ccccc}
\hline Time & $\begin{array}{c}\text { Cycle } \\
\text { Time } \\
\text { (seconds) }\end{array}$ & $\begin{array}{c}\text { Vehicle } \\
\text { per } \\
\text { cycle }\end{array}$ & $\begin{array}{c}\text { Conversion } \\
\text { times } \\
\text { factor }\end{array}$ & $\begin{array}{c}\text { Conversion } \\
\text { (vehicle/hr) }\end{array}$ \\
\hline 08.23 .09 & 66 & 48 & 55 & 2618 \\
08.43 .06 & 58 & 38 & 62 & 2359 \\
\hline
\end{tabular}

\section{QUEUEING ANALYSIS}

In this study, a queue length of vehicles was calculated due to a passing train using queueing analysis method.

Here is an example of the calculation of the queue length on East Jagir Wonokromo Street from east to west direction at 06.33.59, namely:

$\mu \quad=2921$ light vehicle unit/hour

$\mathrm{r} \quad=95$ seconds

$\lambda=189$ light vehicle unit/hour

$\mathrm{L}_{\mathrm{M}} \quad=6$ meter

So that the queue duration is obtained:

$\mathrm{T}_{\mathrm{Q}}=(2921 \times 95) /(2921-189)=102$ seconds

Queue length of vehicles in light vehicle unit:

$\mathrm{Q}_{\mathrm{M}}=\lambda \mathrm{r} /(3600)=(95 \times 189) /(3600)=5 \mathrm{lvu}$

In which the average area used by one light vehicle based on PKJI 2014 is $20 \mathrm{~m}^{2}$, then divided by the width of entry (m), as the following equation so that the queue length is obtained.

$\mathrm{Q}_{\mathrm{M}}=5 \times(20 / 6)=16.67$ meter

\section{COMPARISON OF QUEUE LENGTH RESULT}

In this study, an analysis of the queue length of vehicle due to the gate closing time at level crossing was carried out using 3 methods, namely the calculation using queueing analysis assuming average area of a light vehicle is $20 \mathrm{~m}^{2}$ in according to PKJI 2014, the calculation uses queueing analysis assuming an average area of light vehicle is 11.25 $\mathrm{m}^{2}$ according to observation, and based on survey. The results of the queue length of vehicles on East Jagir Wonokromo Street from east to west direction can be seen in Figure 3 and west to east can be seen in Figure 4.

From Figure 3 and Figure 4 it is known that the results of the queue length of the vehicles with queuing analysis method with assuming average area of light vehicles 11.25 $\mathrm{m}^{2}$ is close to the results of queue length of vehicles from 
observations in the field, while the results of the queue length with assuming average area of light vehicles $20 \mathrm{~m}^{2}$ according to the 2014 PKJI was found very different from the results of the queue length by observation in the field. This is due to differences in driving behavior in the field with the assumptions found in the 2014 PKJI [16].

\section{E. MODEL EQUATIONS}

The first model is the long relationship between the gate closing time at railway level crossing with the length and speed of train using multiple linear regression methods. The results of the analysis using SPSS assistance program can be seen in Table 5 .

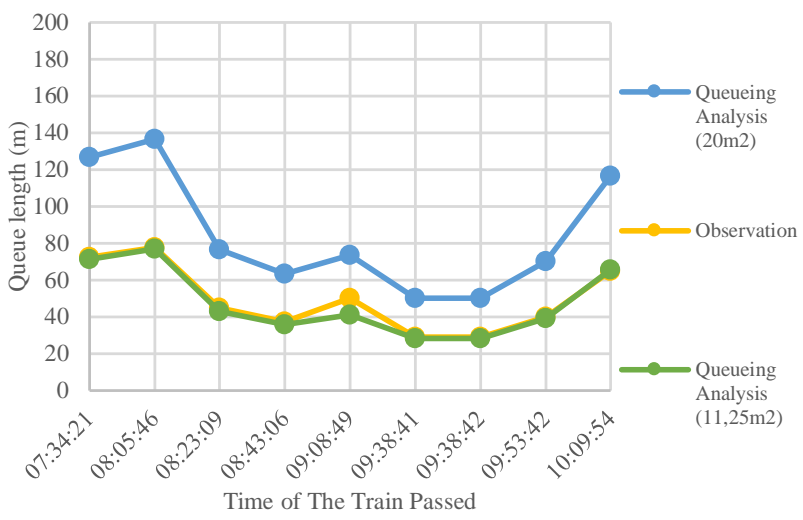

Figure 3 The Result of Queue Length of Vehicles on East Jagir Wonokromo Street from East to West Direction (East Side of Railway Level Crossing) Due to The Gate Closing Time at Railway Level Crossing

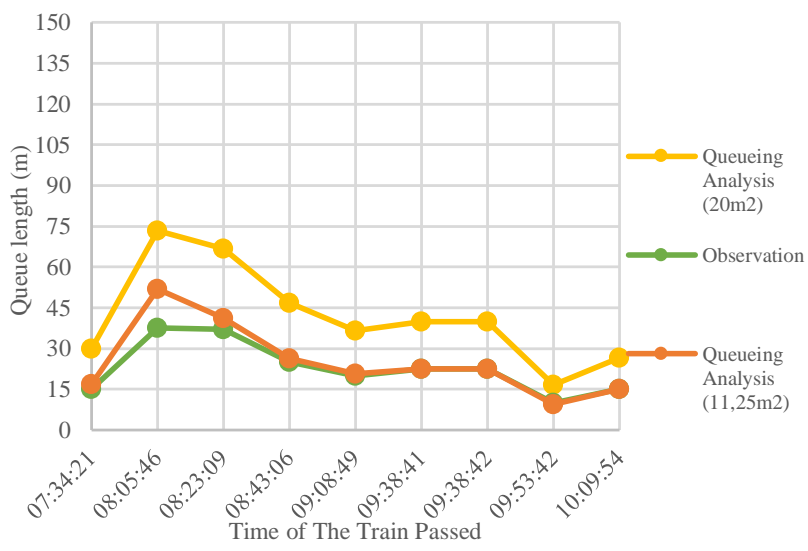

Figure 4 The Result of Queue Length of Vehicles on East Jagir Wonokromo Street from West to East Direction (West Side of Railway Level Crossing) Due to The Gate Closing Time at Railway Level Crossing

Table 5 Output Equation Model and Significance

\begin{tabular}{ccccc}
\hline & Coefficients & $\begin{array}{c}\text { Standard } \\
\text { Error }\end{array}$ & t Stat & P-value \\
\hline $\begin{array}{c}\text { Intercept } \\
\text { Amount } \\
\text { Speed } \\
(\mathrm{km} / \mathrm{h})\end{array}$ & 249.9298 & 8.1717 & 30.584 & $5.441 \mathrm{E}-43$ \\
$\begin{array}{c}\text { Train } \\
\text { Circuit }\end{array}$ & 0.637187 & 0.2207 & 2.886 & 0.005140 \\
\hline
\end{tabular}

The meaning of the equation is that every increase in the speed of the train by $1 \mathrm{~km} / \mathrm{h}$ will decrease the gate closing time of the level crossing and each addition of a series of trains by 2.083 seconds, it also increases the closing time of a level crossing by 0.637 seconds. From the results of the data processed above also obtained significant test data with the results of $P_{\text {value }}$ of the speed of the train circuit is $4.990 \mathrm{E}-43$ smaller than the alpha where the alpha used is 0.05 then it can be stated that the speed of the train there is a significant relationship to the gate closing time of the level crossing. While the number of train circuits with a value of $P_{\text {value }}$ of 0.005140 is less than alpha, the number of train circuits has a significant relationship the gate closing time of the level crossing. Table 6 shows the Adjusted R-Square value of the model's regression result.

Table 6 Adjusted R-square Regression Model Results

\begin{tabular}{cc}
\hline \multicolumn{2}{c}{ Regression Statistics } \\
\hline Multiple R & 0.934497043 \\
R Square & 0.873284724 \\
Adjusted R Square & 0.869764855 \\
Standard Error & 7.812795975 \\
Observations & 75 \\
\hline
\end{tabular}

From the output adjusted $\mathrm{R}$ square value obtained by 0.870 . This value means that the effect of train length and speed on length of time is $87 \%$ while $13 \%$ of the time is influenced by other variables that are not studied.

The second model is the relationship between the duration of the gate closing time at level crossing and the queue length of vehicles using observation result, the result of queuing analysis with the assumption of an average area of light vehicles is $20 \mathrm{~m}^{2}$ according to PKJI 2014, and the result of queuing analysis with the assumption of an average area of light vehicles is $11.25 \mathrm{~m}^{2}$ according to observation. All of them using simple linear regression with Microsoft Excel. In this relationship model is divided into two, namely East Jagir Wonokromo Street from east to west and East Jagir Wonokromo Street from west to east. East Jagir Wonokromo Street needs to be reviewed because the road is congestion and close to a signalized intersection so that if the queue length exceeds the distance between railway level crossings and signalized intersection, it can likely interfere with signalized intersection. In the data used $\mathrm{Y}$ is the duration gate closing time and $\mathrm{X}$ is the queue length.

The relationship between the duration of the gate closing time and the results of queue length by queueing analysis assuming a light vehicle of $20 \mathrm{~m}^{2}$ on East Jagir Wonokromo Street from east to west direction (east side of railway level crossing) as shown in Figure 5. From the picture obtained the equation of the model formed is $\mathrm{y}=$ $1.1298 x+0.7881$ with the value of $\mathrm{R}$-Square is 0.903 . The equation assumes the meaning that every 1 second increase of gate closing time, it will increase the queue length by $1.1298 \mathrm{~m}$.

The relationship between the duration of the gate closing time and the results of queue length by queueing analysis assuming a light vehicle of $20 \mathrm{~m}^{2}$ on East Jagir Wonokromo Street from west to east direction (west side of railway level crossing) as shown in Figure 6. From the 


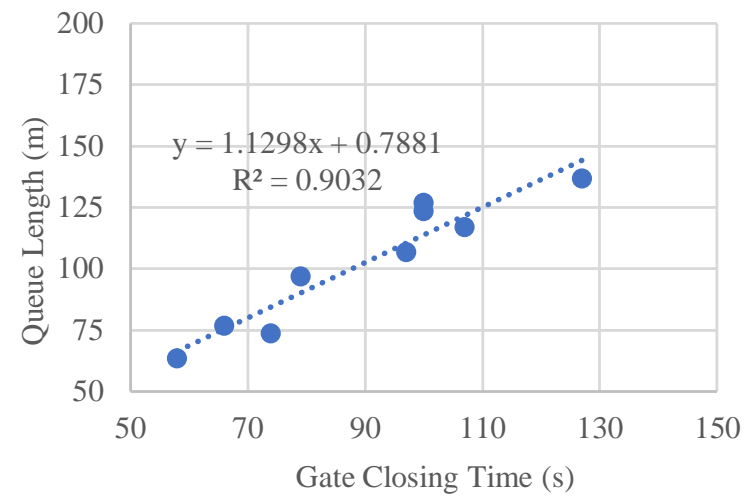

Figure 5 Linear Regression Chart Relationship Duration of Gate Closing Time and The Result of Queue Length Assuming a Light Vehicle of $20 \mathrm{~m}^{2}$ on East Jagir Wonokromo Street from East to West Direction

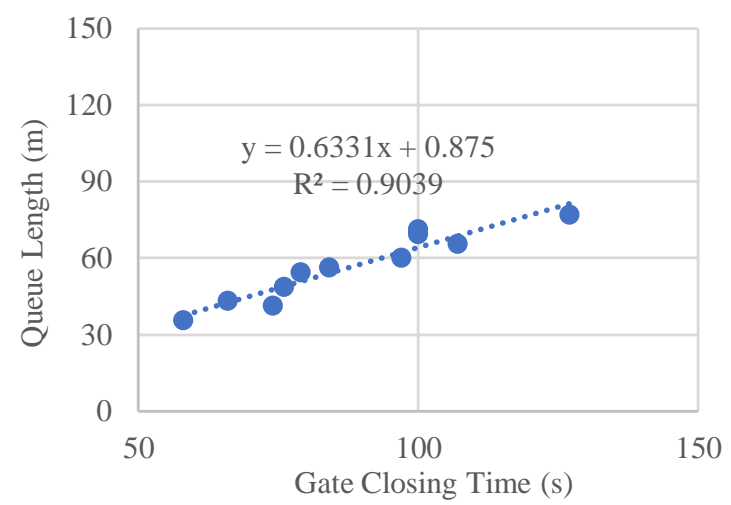

Figure 7 Linear Regression Chart Relationship Duration of Gate Closing Time and The Result of Queue Length Assuming a Light Vehicle of $11.25 \mathrm{~m}^{2}$ on East Jagir

Wonokromo Street from East to West Direction

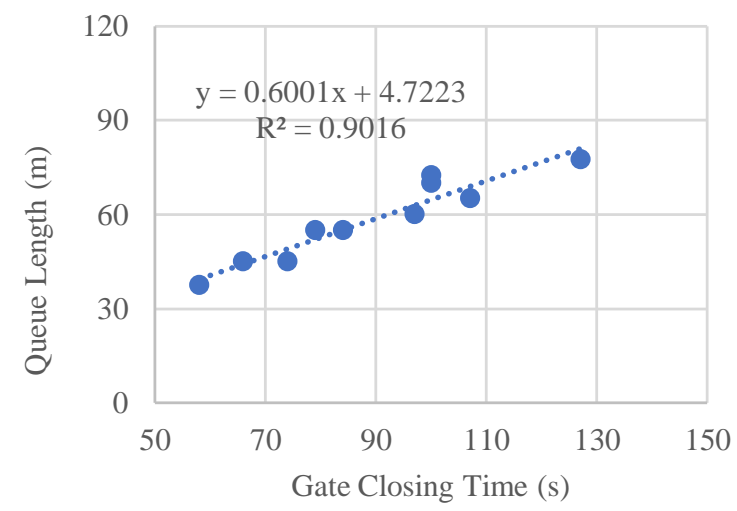

Figure 9 Linear Regression Chart Relationship Duration of Gate Closing Time and The Result of Queue Length by Observation on East Jagir Wonokromo Street from East to West Direction

picture obtained the equation of the model formed is $\mathrm{y}=$ $0.3617 \mathrm{x}-2.0079$ with the value of $\mathrm{R}$-Square is 0.424 . The equation assumes the meaning that every 1 second increase of gate closing time, it will increase the queue length by $0.3617 \mathrm{~m}$.

The relationship between the duration of the gate closing time and the results of queue length by queueing analysis assuming a light vehicle of $11.25 \mathrm{~m}^{2}$ on East Jagir

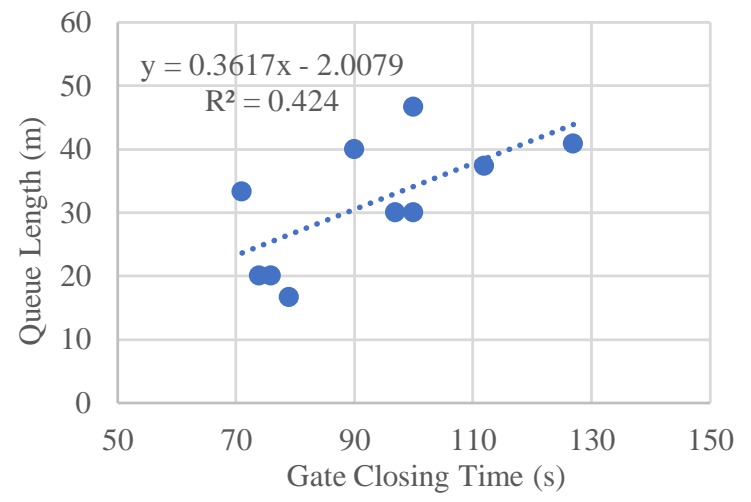

Figure 6 Linear Regression Chart Relationship Duration of Gate Closing Time and The Result of Queue Length

Assuming a Light Vehicle of $20 \mathrm{~m}^{2}$ on East Jagir Wonokromo Street from West to East Direction

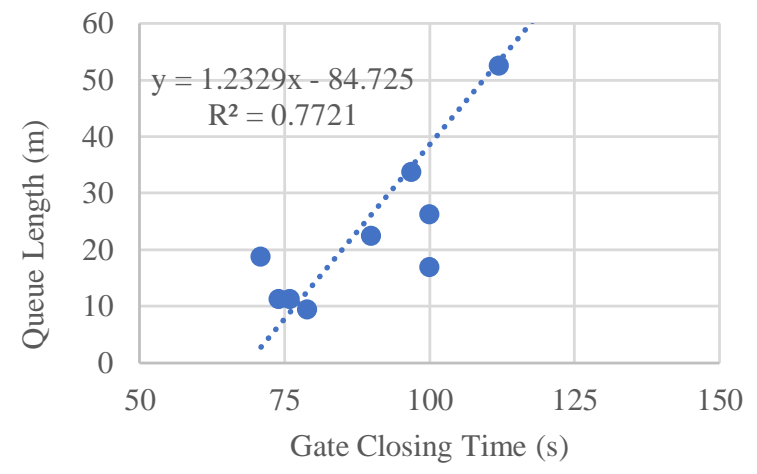

Figure 8 Linear Regression Chart Relationship Duration of Gate Closing Time and The Result of Queue Length Assuming a Light Vehicle of $11.25 \mathrm{~m}^{2}$ on East Jagir Wonokromo Street from West to East Direction

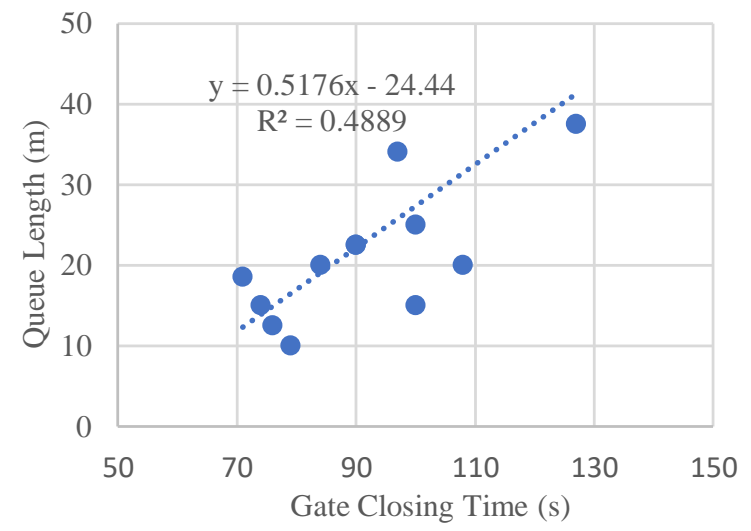

Figure 10 Linear Regression Chart Relationship Duration of Gate Closing Time and The Result of

Queue Length by Observation on East Jagir Wonokromo Street from West to East Direction

Wonokromo Street from east to west direction (east side of railway level crossing) as shown in Figure 7. From the picture obtained the equation of the model formed is $\mathrm{y}=$ $0.6331 \mathrm{x}-0.875$ with the value of R-Square is 0.9039 . The equation assumes the meaning that every 1 second increase of gate closing time, it will increase the queue length by $0.6331 \mathrm{~m}$. 
The relationship between the duration of the gate closing time and the results of queue length by queueing analysis assuming a light vehicle of $11.25 \mathrm{~m}^{2}$ on East Jagir Wonokromo Street from west to east direction (west side of railway level crossing) as shown in Figure 8. From the picture obtained the equation of the model formed is $\mathrm{y}=$ $1.2329 x+84.725$ with the value of R-Square is 0.7721 . The equation assumes the meaning that every 1 second increase of gate closing time, it will increase the queue length by $1.2329 \mathrm{~m}$.

The relationship between the duration of the gate closing time and the results of queue length by observation on East Jagir Wonokromo Street from east to west duration (east side of railway level crossing) as shown in Figure 9. From the picture obtained the equation of the model formed is $y=0.6001 x+4.7223$ with the value of $R$-Square is 0.902 The equation assumes the meaning that every 1 second increase of gate closing time, it will increase the queue length by $0.6001 \mathrm{~m}$.

The relationship between the duration of the gate closing time and the results of queue length by observation on East Jagir Wonokromo Street from west to east direction (west side of railway level crossing) as shown in Figure 10. From the picture obtained the equation of the model formed is $y=0.5176 x+24.44$ with the value of $R$-Square is 0.489 The equation assumes the meaning that every 1 second increase of gate closing time, it will increase the queue length by $0.489 \mathrm{~m}$.

There are differences in the linear regression equation between the result of queue length with assuming a light vehicle area of $20 \mathrm{~m}^{2}$ according to PKJI 2014, the result of queue length with assuming a light vehicle area of 11.25 $\mathrm{m}^{2}$ according to observation and the result of queue length by observation at research site. This is due to differences in the assumptions of driving behavior on real condition. Driving behavior in question is the driving behavior in following each other vehicles or maintaining a safe driving distance between one vehicle to another, driving behavior in overtaking other vehicles, and driving behavior in maintaining a side distance from one vehicle to another [16].

\section{CONCLUSIONS}

This paper examines that railway level crossing located nearby signalized intersection can affect the signalized intersection performance. Gate closing time at railway level crossing can cause queue length of vehicle. If railway level crossing located nearby signalized intersection, the queue length of vehicle can reach signalized intersection and can make traffic problem. Some conclusion obtained from some of the result in this paper are as follows.

The result of linear regression analysis of the relationship between the length of train and speed of train with gate closing time has a significant effect. There was a positive relationship between the length of train with gate closing time and negative relationship between the speed of train with gate closing time. So, duration gate closing time at railway level crossing depends on the length and speed of the train.

The result of linear regression model of the relationship duration of gate closing time and the result of queue length on east side and west side of East Jagir Wonokromo Street have a positive relationship. The equation model between the duration gate closing time and the results of queue length by queueing analysis assuming a light vehicle of 20 $\mathrm{m}^{2}$ on East Jagir Wonokromo Street from east to west direction (east side of railway level crossing) is $\mathrm{y}=1.1298 \mathrm{x}$ +0.7881 , while on East Jagir Wonokromo Street from west to east (west side of railway level crossing) is $\mathrm{y}=0.3617 \mathrm{x}$ -2.0079 . The equation model between the duration gate closing time and the results of queue length by queueing analysis assuming a light vehicle of $11.25 \mathrm{~m}^{2}$ on East Jagir Wonokromo Street from east to west direction (east side of railway level crossing) is $\mathrm{y}=0,6001 \mathrm{x}+4,7223$, while on East Jagir Wonokromo Street from west to east direction (west side of railway level crossing) is $\mathrm{y}=1.2329 \mathrm{x}+$ 84.725. The equation model between the duration gate closing time and the results of queue length by observation on East Jagir Wonokromo Street from east to west directon (east side of railway level crossing) is $\mathrm{y}=0.6001 \mathrm{x}+$ 4.7223, while on East Jagir Wonokromo Street from west to east direction (west side of railway level crossing) is $\mathrm{y}=$ $0.5176 \mathrm{x}+24.44$.

There are differences in the linear regression equation model between the result of queue length with assuming a light vehicle area of $20 \mathrm{~m}^{2}$ according to PKJI 2014, the result of queue length with assuming a light vehicle area of $11,25 \mathrm{~m}^{2}$ according to observation, and the result of queue length by observation at research site. This is due to differences in the assumptions of driving behavior on real condition. Driving behavior in question is the driving behavior in following each other vehicles or maintaining a safe driving distance between one vehicle to another, driving behavior in overtaking other vehicles, and driving behavior in maintaining a side distance from one vehicle to another.

\section{REFERENCES}

[1] Badan Pusat Statistik Provinsi Jawa Timur, "Jawa Timur dalam Angka 2017," 2017.

[2] Badan Pusat Statistik Kota Surabaya, "Surabaya dalam Angka 2018," 2018.

[3] Badan Pusat Statistik Kota Surabaya, "Surabaya dalam Angka 2015," 2015.

[4] D. M. Mali, P. N. F. Umrigar, and P. P. N. A, "Study of Congestion of the Road Traffic at Railway Crossings," International Advanced Research Journal in Science, Engineering and Technology, vol. 4, no. 3, pp. 147-150, 2017, doi: 10.17148/iarjset.2017.4327.

[5] Undang-Undang Republik Indonesia Nomor 23 Tahun 2007, Tentang Perkeretaapian, no. 235. 2007, p. 245.

[6] X. L. dan L. CHENG, "Traffic Congestion Research of Road and Railway Intersections,” pp. 346-359, 2011.

[7] C. De Gruyter and G. Currie, "Rail-road crossing impacts: an international synthesis," Transport Reviews, vol. 36, no. 6, pp. 793-815, 2016, doi: 10.1080/01441647.2016.1188429.

[8] A. S. Amal, "Pengaruh penutupan pintu perlintasan kereta api terhadap tundaan dan panjang antrian pada jalan raya malang - surabaya km.10," no. x, pp. 85$89,2003$. 
[9] Kementerian PU, "Kapasitas simpang apill," Pandu. Kapasitas Jalan Indones., p. 95, 2014.

[10] K. PU, "Pedoman Kapasitas Jalan Perkotaan," p. 70, 2014.

[11] H. Widyastuti, A. Utami, and Z. M. Dzulfiqar, "Model of queuing in the railway level crossing (case study: Imam Bonjol railway level crossing in Blitar)," IOP Conference Series: Materials Science and Engineering, vol. 650, no. 1, pp. 0-9, 2019, doi: 10.1088/1757-899X/650/1/012053.

[12] I. Setiyaningsih, "Karakteristik Lalu Lintas Pada Persilangan Sebidang Jalan dan Jalan Rel," 2007.

[13] A. D. May, "Traffic Flow Fundamentals." p. 464, 1990, [Online]. Available: http://books.google.com/books?id=JYJPAAAAMA AJ\&pgis $=1$.

[14] H. Widyastuti, A. Utami, and M. I. Putra, "Model of Queuing in the Railway Level Crossings (Case Study: Railway Level Crossings in Jemursari Surabaya) Hera," IOP Conference Series: Materials Science and Engineering, vol. 650, no. 1, pp. 225-232, 2019, doi: 10.1088/1757-899X/650/1/012053.

[15] J. Supratno, "Statistik Teori dan Aplikasi Edisi Keenam Jilid 1.” p. 11, 2000, [Online]. Available: https://books.google.co.id/books?id=A0Ov5OpbXA gC\&pg=PA1 $\&$ dq $=$ statistik \&hl=id\&sa $=X \& v e d=0 a h$ UKEwiqmZjjKXoAhVQfH0KHV96CiwQ6AEIUTAG\#v=onepa ge $\& \mathrm{q}=$ statistik $\& \mathrm{f}=$ false.

[16] D. A. Susetyo, "Analisis kinerja lalu lintas pada perlintasan kereta api sebidang dengan mikrosimulasi," no. 10, 2020. 